\title{
Emotional exhaustion and organizational commitment: Primary school teachers' perspective
}

\author{
Mozes M. Wullur'1, Basilius Redan Werang ${ }^{2}$ \\ ${ }^{1}$ Faculty of Educational Sciences, Universitas Negeri Manado, Indonesia \\ ${ }^{2}$ Faculty of Teacher Training and Education, Universitas Musamus, Indonesia
}

\section{Article Info \\ Article history: \\ Received May 8, 2020 \\ Revised Sep 21, 2020 \\ Accepted Oct 20, 2020}

\section{Keywords:}

Emotional exhaustion Organizational commitment Primary school

Teacher

\begin{abstract}
Teaching is a noble profession to educate the youth of nations facing today's global challenges. Teaching, at the same time, has become a highly challenging profession and occasionally a draining work, especially for those who are working in the remote areas. A high-level of teacher absenteeism in the primary schools of Southern Papua has blown some societal alarm for conducting studies focusing on emotional exhaustion as a latent predictor for low-performance. This study attempted to describe the eventual correlation between the emotional exhaustion and organizational commitment of teachers working in the primary schools of Merauke, Indonesia. A survey approach was employed to collect data from a total of 243 primary school teachers in Merauke, Papua, Indonesia. Data were examined statistically by employing Pearson's correlation model. Results of analysis showed that the emotional exhaustion and commitment of primary school teachers in Merauke, Indonesia, are significantly negatively correlated. This result may be useful for the teachers to benefit from the information of how they may interact with all the school elements and the extent to which these emotions directly affect their organizational commitment. The result may also be advisable for the school leaders to take some tactical efforts of securing teachers' emotion to promote a high-level of teachers' organizational commitment and, in turn, improving students' capabilities in reading, writing, and arithmetics.
\end{abstract}

This is an open access article under the CC BY-SA license.

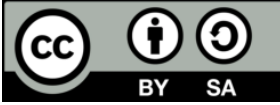

\section{Corresponding Author:}

Basilius Redan Werang,

Faculty of Teacher Training and Education,

Universitas Musamus,

Jln. Kamizaun, Mopah Lama, Merauke 99611, Papua, Indonesia.

Email: lirang267@yahoo.co.id

\section{INTRODUCTION}

Teaching is a highly challenging profession [1] and occasionally a draining work [2]. A high-level of teacher absenteeism in the primary schools [3,4] has blown some societal alarm for conducting researches on teachers' emotional exhaustion as a potential predictor for teachers to be away from his or her school and engaging with other exciting activities. Werang [5] has clearly noticed that teachers' emotional exhaustion has not just affected on teacher's behavior but also affected greatly on the teachers' physical and psychological health.

Despite the accessible previous studies considered either the contributing factors to teacher emotional exhaustion [6-13] or the impact of teacher emotional exhaustion [14-21], we are encouraged to explore more this subject matter to address Werang, et al. [3, 4] findings that low level of teacher's organizational commitment was predicted most by teachers' working conditions (e.g. remoteness, 
unavailability of healthy and well-equipped school accommodations, lack of local community ties) in which teachers could be emotionally strained and worn-out.

Emotional exhaustion is the core facet of burnout [22-29] and become the best indicator of burnout [30, 31]. Not surprisingly if some researchers [32] have even measured burnout with emotional exhaustion alone. Emotional exhaustion is a persistent condition of feeling emotionally worn-out resulting from an excessive job, personal demands, and, or accumulated stress [33], while Gemlik, et al. [34] saw emotional exhaustion as the feelings of being mentally depleted by one's interaction with others. Whereas Donahue, et al. [35] saw emotional exhaustion as the feelings of being emotionally consumed and feelings of extreme tiredness resulting from the chronic burden placed on a person.

Emotional exhaustion usually happens with physical tiredness, and its indicators involve lack of vitality, trouble sleeping, irrational anger, apathy, problems in the family, sense of dread, increased cynicism or pessimism, and an increase in drinking [36, 37]. When a worker is mentally drained, then he or she will no longer stay in a particular organization [38]. A worker with an excessive level of emotional exhaustion tend to be absent from and uncommitted to the work of organization

The term emotional exhaustion here denotes to teachers' emotional exhaustion, which is seen as teachers' persistent condition of being physically and mentally washed-out, resulting from a long-term workplace stress. Prior studies have identified some sources of teachers' emotional exhaustion, both on the school level (such as school climate, poor working conditions, and students' misbehavior) and the individual level (such as teachers' self-efficacy) [5, 39, 40].

Emotional exhaustion has widely been known by researchers [38, 41, 42] as linked to organizational commitment. Organizational commitment has been described in different ways. Scholl [43] described organizational commitment as the stabilizing power to preserve behavioral direction when desired circumstances do not happen adequately. In a similar vein, Brickman [44] described organizational commitment as a force that stabilizes an employee's behavior under circumstances where he or she would otherwise be attracted to change that behavior. Whereas Gozález and Guillèn [45] described organizational commitment as a deliberate decision of a worker to attach or bound to a particular organization. This deliberate decision, in turn, may lead to a high-or-low-level of personal attachment to that organization. This attachment is usually observed in the personal eagerness to accomplish the works of organization.

In the educational context, teachers' organizational commitment is simply described as a teacher's voluntary decision to be an integrated part of a particular educational institution and to actively be involved in bringing the light for the youth of nations. Webrecruit Ireland [46] identified some characteristics of the high committed teachers as follows: (a) presenting appetite for the new difficulties' challenges: a high dedicated teacher looks for new challenges. A high dedicated teacher is always hungry for something new and is happier at schools that permit him/her to extinguish that hunger; (b) presenting problem-solving demeanor: whatever problem may come, a high-dedicated teacher is able to get the way to solve it even without any instruction from the leader; (c) showing enthusiasm to lead: a high-dedicated teacher knows what works should be done and how to do such functions to the best possible standard, and come up with his/her way to resolve problems within the school; (d) showing work and profession fulfilment: a high-dedicated teacher tends to be very happy with his/her work and career, and; (e) presenting more exceptional behavior: a high-dedicated teacher tends to perform the best. Whereas the low dedicated teacher can create many difficulties for the schools in pursuing educational goals. The Kotton Mouth Kings Team [47] identified some characteristics of the low dedicated teachers as follows: (a) presenting fewer attention in improvement; (b) performing less concern in pleasing their superior than before; (c) showing hesitant to bind with long-term assignments, and; (d) performing the least of required work.

Keeping on the view of teachers' capability in shaping their own commitment to teach the nation's youth, school principals remain a very important role in determining the high-or-low-level of teachers' commitment. Aside from the pivotal role played by the school principals, the accessible studies/literature have highlighted how emotional exhaustion, as the core aspect of burnout, determines organizational commitment. Khan, et al. [38] assessed academicians' emotional exhaustion and its prospective effect on their organizational commitment. Using the Maslach Burnout Inventory (MBI) and Meyer and Allen's items of the questionnaire as tools for collecting data, the study found that emotional exhaustion and the organizational commitment of academicians is negatively related.

Churiyah [41] assessed how the conflict of role and emotional exhaustion affect teacher job satisfaction and organizational commitment in MAN 3 Malang, Indonesia. The participants of the study comprised 64 teachers. Applying the path analysis as the tool of data analysis, the result showed that the conflict of role and emotional exhaustion do not affect directly the commitment of teachers to the organization (school). The result, in reverse, showed that the conflict of role and emotional exhaustion affect indirectly teacher organizational commitment in MAN 3 Malang, Indonesia, through their job satisfaction. 
Rosa [42] assessed the impact of role conflict and emotional exhaustion on job satisfaction and organizational commitment of nurses in Muhammadiyah Gamping Hospital. Data were collected from a total of 55 nurses working in Muhammadiyah Gamping Hospital. Using Partial Least Squares (PLS) as a tool of data analysis, the study showed a negative impact of role conflict and emotional exhaustion on the organizational commitment of nurses working in Muhammadiyah Gamping Hospital.

Akdemir [48] assessed the burnout and how it affects teachers' organizational commitment in the Turkish context. Participants of the study comprised 173 teachers. The study employed the Maslach Burnout Inventory and Organizational Commitment Scale as the instruments of data collection. Using multiple regression analysis techniques by applying Statistical Package for the Social Sciences (SPSS) as the tools of data analysis, the result revealed that the organizational commitment of teachers was significantly positively predicted by their job burnout.

Haghani, et al. [49] assessed the prospective relationship between the burnout and organizational commitment of social security workers using the demographic variables as moderator. The informants of the study comprised 124 social security workers in Mazandaran Province, Iran. Applying Pearson's correlation as the tool of data analysis, the result showed that burnout and organizational commitment of social security workers are significantly correlated.

Hutomo [50] assessed the prospective relationship between the burnout and organizational commitment of workers in the State Personnel Agency Office in Jayapura, Indonesia. The participants of the study comprised 100 workers. Applying the Pearson's correlation as the tool of data analysis, the result showed that the coefficient value of Pearson's correlation is .850 with the coefficient value of Sig. $=.000$. Based on this result, the researcher concluded that the burnout and organizational commitment of workers are significantly positively correlated. At the end of the study, the researcher recommended a need for the head of office to eliminate the feeling of burnout among workers to promote the high commitment of workers to their organization

Sariişik, et al. [51] assessed the prospective relationship between the burnout and organizational commitment of 700 public officers in Istanbul. Applying the Partial Least Squares as a tool of data analysis, the results of the study were as the following: (a) a negative relationship exists between the emotional exhaustion and organizational commitment among public officers in Istanbul; (b) a positive relationship exists between the personal accomplishment and organizational commitment among public officers in Istanbul; and (c) a no significant relationship between the experience of depersonalization and all the three dimensions of burnout.

Bavani, et al. [52] assessed the prospective impact of burnout dimensions on organizational commitment of 383 employees of Melaka manufacturing industries. The results of the study were as the following: (a) a negative and significant association exists between the emotional exhaustion and experience of depersonalization with the organizational commitment of the employees working in Melaka manufacturing industries; and (b) a positive association exists between the personal accomplishment and organizational commitment of the employees working in Melaka manufacturing industries.

Despite the similar findings that might exist between this study and the previous ones, the finding of this study may hypothetically enlarge the existing knowledge on this subject matter by stipulating a valuable information from the actual context of Merauke, Indonesia. As this study attempted to describe the eventual correlation between the emotional exhaustion and organizational commitment of teachers working in the primary schools of Merauke, Indonesia, the study was guided by the following research questions: "Does a negative and significant correlation exist between the emotional exhaustion and organizational commitment of teachers working in the primary schools of Merauke, Indonesia?" Based on the related literature exploring the emotional exhaustion of teachers and how it predicts their organizational commitment, in this study, we do believe that emotional exhaustion and organizational commitment of teachers working in the primary schools of Merauke, Indonesia, will be significantly negatively correlated. In fact, many primary school teachers of Merauke, despite of being physically and emotionally exhausted, remain committed to teach the youth of nation.

\section{RESEARCH METHOD}

This study attempted to justify how the emotional exhaustion correlates with teacher commitment in the primary schools of Merauke, Papua, Indonesia. This study, in its very nature, is a quantitative research. A survey approach was used as it offers the following six benefits: (a) low-priced, (b) helpful data collection, (c) high representation, (d) truthful outcome, (e) suitable arithmetical outcome, and (f) little investigator prejudice $[53,54]$. Incidental sampling technique was used to select a total of 243 primary school teachers of Merauke as informants because most of the sub-districts are inrural and swampy remote areas. Topographical features of the sub-district and the number of participants in each district are shown in Table 1. 
Table 1. Topographical features of sub-district

\begin{tabular}{ccccc}
\hline Sub-District & Location & Area $(\mathrm{km})$ & Schools & Informants \\
\hline Kimaam & Swampy Remote & $4,630,30$ & 8 & 15 \\
Waan & Swampy Remote & $2,868,06$ & 8 & 2 \\
Tabonji & Swampy Remote & $5,416,84$ & 6 & 5 \\
Ilwayab & Swampy Remote & $1,999,08$ & 5 & 5 \\
Okaba & Remote & $1,560,50$ & 11 & 15 \\
Tubang & Remote & $2,781,18$ & 6 & 2 \\
Ngguti & Remote & $3,554,62$ & 7 & 2 \\
Kaptel & Remote & $2,384,05$ & 5 & 2 \\
Kurik & Rural & 977,05 & 12 & 25 \\
Anim Ha & Rural & $1,465,60$ & 5 & 15 \\
Malind & Rural & 490,60 & 7 & 15 \\
Merauke & Urban & $1,445,63$ & 36 & 50 \\
Naukenjerai & Rural & 905,86 & 5 & 5 \\
Semangga & Sub-urban & 326,95 & 11 & 20 \\
Tanah Miring & Sub-urban & $1,516,67$ & 16 & 25 \\
Jagebob & Rural & $1,364,96$ & 14 & 10 \\
Sota & Rural & $2,843,21$ & 6 & 8 \\
Muting & Rural - remote & $3,501,67$ & 12 & 10 \\
Eligobel & Rural - remote & $1,666,23$ & 12 & 6 \\
Ulilin & Rural - remote & $5,092,57$ & 11 & 6 \\
& Total & $46,791,63$ & 203 & 243 \\
\hline
\end{tabular}

To measure primary school teacher's perceptions of emotional exhaustion, we used a questionnaire of 7 items from a current study [5]. The list of items used a four-point Likert's scale, marked from 1 (strongly disagree) to 4 (strongly agree). Sample of questionnaire are following: "I feel I get tired of my current job," "I feel that I have lost my enthusiasm about my profession," "I feel spiritually exhausted when arrive at home after work," "I feel I get exhausted at work both emotionally and cognitively," "My shifts at work make me exhausted," "Working with people all day long constitutes a serious burden for me," and "It makes me stressful to be in direct communication with people." The Cronbach's alpha coefficient was used to test the instrument's reliability. The coefficient value of Cronbach's alpha was 0.751 .

To measure primary school teacher's perceptions of organizational commitment, we used a questionnaire of 15 items from a current study [55]. The list of items used a four-point Likert's scale, marked from 1 (strongly disagree) to 4 (strongly agree). Sample of items are following: "I tell my friends this is a good organization to work for," "I am proud to tell others that I am part of this organization," "I understand how my job contributes to the organization's goals and objectives," "I have a good understanding of where the organization is going," "I find that my values and organization's values are very similar," "I am willing to put in a great deal of extra effort to help this organization be successful," "I am extremely thrilled that I chose to work here rather than one of the other jobs I was considering at the time I joined," "I really care about the fate of this organization," "my organization inspires the best job performance from me," "I work in a wellmanaged organization," and "morale in this organization is good." The Cronbach's alpha coefficient was used to test the instrument's reliability. The coefficient value of Cronbach's alpha was 0.723.

Pearson's correlation was used to analyze data. To have a more precise result, the statistical software of SPSS was employed. The study worked under a proposed research hypothesis $\left(\mathrm{H}_{\mathrm{a}}\right)$ as the following: the emotional exhaustion and organizational commitment of teachers working in the primary schools of Merauke, Indonesia, will be significantly negatively correlated. Meanwhile, the null hypothesis is that the emotional exhaustion and organizational commitment of teachers working in the primary schools of Merauke, Indonesia, will be significantly substantial correlated. These hypotheses will statistically be tested with the coefficient of alpha $(\alpha) .05$.

\section{RESULTS AND DISCUSSION}

This paper provided findings from a study using a survey research design in which the correlation between the emotional exhaustion and organizational commitment of teachers was recorded from a total of 243 primary school teachers of Merauke, Indonesia. As aforesaid that collected data were analyzed statistically using Pearson's correlation. The significant relationship between the two research variables is shown in Table 2. 
Table 2. Result of Pearson's correlation analysis

\begin{tabular}{|c|c|c|c|c|c|c|}
\hline \multicolumn{7}{|c|}{ Coefficients $^{\mathrm{a}}$} \\
\hline \multirow{2}{*}{\multicolumn{2}{|c|}{ Model }} & Unstandar & Coefficients & Standardized Coefficients & $\mathrm{T}$ & Sir \\
\hline & & $\mathrm{B}$ & Std. Error & Beta & 1 & Sig. \\
\hline \multirow{2}{*}{1} & (Constant) & 64.230 & 1.918 & & 33.493 & .000 \\
\hline & Emotional_Exhaustion & -.458 & .087 & -.322 & -5.271 & .000 \\
\hline
\end{tabular}

Table 2 reveals that the emotional exhaustion and organizational commitment of primary school teachers of Merauke, Indonesia are significantly negatively correlated as the $\beta$ coeficient value of -.322 is significant at the level of $\alpha=0.05$. Since the $\beta$ coefficient value is significant negative at the value of alpha $(\alpha)=.05$, then the research hypothesis that the emotional exhaustion and organizational commitment of teachers working in the primary schools of Merauke, Indonesia, will be significantly negatively correlated is confirmed, while the null hypothesis is unconfirmed. As the $\beta$ coefficient value is significant negative means that adding one point/digit in teachers' emotional exhaustion will reduce .322 point/digit on teachers' organizational commitment, while lowering one point/digit on teachers' emotional exhaustion will add .322 point/digit on teachers' organizational commitment. In other words, the teachers with a higher level of emotional exhaustion will demonstrate a lower level of organizational commitment to the teaching profession and vice versa. The result of this study confirmed Khan, et al. [38] research findings that the emotional exhaustion and the organizational commitment is significantly negatively correlated. The finding of this study also confirmed Gemlik, et al. [34] research findings that the emotional exhaustion, the core component of burnout, has a meaningful descriptive power towards affective and normative commitment $(53.3 \%$ and $32.6 \%$ respectively). The finding of this study seemed not in line with Zhen's [21] research findings. In his research Zhen [21] reached the conclusion that it is not accurate to predict employees' organizational commitment based on their emotional exhaustion due to that those employees with high emotional exhaustion may not necessarily have low organizational commitment.

Emotional exhaustion has already been one of the prevalent psychological dispositions facing the remote primary school teachers of Papua, Indonesia. This mental disposition affects significantly teachers' organizational commitment and performance. Teachers with the high level of organizational commitment and low level of emotional exhaustion are likely to demonstrate high performance to achieve school success, highly committed and passionate, little resignation and absenteeism, and high-quality services [34]. Teachers will grow more uncommitted to the teaching profession when they are emotionally exhausted. Chronic emotional exhaustion can reduce teachers' enthusiasm to perform the best and, in turn, damage the high quality of educational practices $[56,57]$. On the contrary, teachers will grow more committed to the teaching profession when they are emotionally happy. The happy teachers tend to be more dedicated and passionate in bringing light to the future generation of nations.

The role of teachers in guaranteeing that students' academic outcomes increase every school year is of importance as they are responsible for the class and the course alike. Since teaching is one of the most exhausting occupation [2], result of this study provided a vision for the school leaders to design efforts of securing teachers' emotion to promote the job satisfaction and organizational commitment of primary school teachers and, in turn, to improve students' capabilities in 3Rs. To foster teachers' commitment to improving primary school students' capability in 3Rs, having a caring, sympathetic, and high-performing school principal is urgently needed $[58,59]$ because school principals take on a key leadership role in creating the social working conditions that may greatly affect teachers' organizational commitment. Principals who provide a vision for the teachers to do their work together. Furthermore, the principals who clarifies these visions clearly will make a huge change in teachers' teaching-learning process [60].

\section{CONCLUSION}

In the primary school teachers studied, the results of data analysis suggested that the effort of reducing teachers' emotional exhaustion might contribute favorably and substantially to the improvement of teachers' organizational commitment. It means that lower levels of teachers' emotional exhaustion, the higher teachers' organizational commitment in the primary schools of Merauke, Indonesia. Practical consequences of the finding are following: (a) since this study dealt with teachers' emotional exhaustion, primary school teachers of Merauke may benefit from the information of how they might interact with all the school elements and the extent to which these emotions affect directly to their job satisfaction and organizational commitment; and (b) this study provided an insight for the school leaders to manage teacher's emotional exhaustion in order that the organizational commitment of the primary school teachers of Merauke, Indonesia would be promoted adequately. Since the research on this topic is still rare, the results of 
this study may hypothetically add the accessible sources on the subject of teachers' emotional exhaustion and organizational commitment.

This study has a limitation in terms of the research area and sample size. To the research area, this study was conducted only in the primary schools of Merauke, Indonesia. While to the sample size, this study involved 243 teachers only. Therefore, future research with a broader areas and a more significant participants will thoroughly be endorsed to generalize the findings. Besides, the scope of the research area should also be expanded to better understand the phenomenon of teachers' emotional exhaustion and its eventual impact on the school's life.

\section{ACKNOWLEDGEMENT}

First and above all we would like to express our utmost gratitude to Lord for granting us the perseverance to complete this study. We also would like to extend our heartfelt gratitude to all the teachers who have contributed in a special way to the study. Our special words of thanks should also go to our family and friends for their constant support and encouragement.

\section{REFERENCES}

[1] K. Wolomasi, S. I. Asaloei, and B. R. Werang, "Job satisfaction and performance of elementary school teachers," International Journal of Evaluation and Research in Education, vol. 8, no. 4, pp. 575-580, 2019.

[2] M. M. Keller, M. L. Chang, E. S. Becker, T. Goetz, and A. C. Frenzel, "Teacher emotional experience and exhaustion as predictors of emotional labor in the classroom: An experience sampling study, Frontiers in Psychology, vol. 5, no. 1442, 2014. [Online]. Available: https://doi.org/10.3389/fpsyg.2014.01442

[3] B. R. Werang, S. M. R. Leba, and E. A. G. Pure, "Factors influencing teacher absenteeism in the remote elementary schools of Indonesia: Empirical proof from Southern Papua," International Journal of Management in Education, vol. 11, no. 3, pp. 223-247, 2017.

[4] B. R. Werang, A. A. G. Agung, and A. A. Hurit, "Increasing teacher attendance in Indonesia: A longitudinal study in the remote elementary schools of Southern Papua," International Journal of Management in Education, vol. 13, no. 2, pp. 133-155, 2019.

[5] B. R. Werang, "The effect of workload, individual characteristics, and school climate on teachers' emotional exhaustion in elementary schools of Papua," Cakrawala Pendidikan, vol. 37, no. 3, pp. 457-469, 2018.

[6] N. H. Basim, M. Begenirbas, and R. Yalçim, "Effects of teacher personalities on emotional exhaustion: Mediating role of emotional labor," Educational Sciences: Theory and Practice, vol. 13, no. 3, pp. 1488-1496, 2013.

[7] J. Davidson and M. Smith, "Austistic authobiographies and more-than-human geograpgies," Environment and Planning D: Society and Space, vol. 27, no. 5, pp. 898-916, 2009.

[8] J. Margolis, "When teachers face teachers: Listening to the resource 'right down the hall'," Teaching Education, vol. 19, no. 4, pp. 293-310, 2008.

[9] M. Skaalvik and S. Skaalvik, "Does school context matter? Relations with teacher burnout and job satisfaction," Teaching and Teacher Education, vol. 25, no. 3, pp. 518-524, 2009.

[10] M. Skaalvik and S. Skaalvik, "Teacher self-efficacy and teacher burn-out: A study of relations," Teaching and Teacher Education, vol. 26, no. 4, pp. 1059-1069, 2010.

[11] S. Sonnentag, et al., "Job stressors, emotional exhaustion, and need for reecovery: A multy-source study on the benefits of psychological detachment," Journal of Vocational Behavior, vol. 76, no. 3, pp. 355-365, 2010.

[12] C. N. Tsouloupas, R. L. Carson, R. Matthews, M. J. Grawitch, and L. K. Barber, "Exploring the association between teachers' perceived student misbehaviour and emotional exhaustion: The importance of teacher's efficacy beliefs and emotion regulation," Educational Psychology, vol. 30, no. 2, pp. 173-189, 2010.

[13] X. Yao, "How school climate influences teachers' emotional exhaustion: The mediating role of emotional labor," International Journal of Environmental Research and Public Health, vol. 12, no. 10, pp. 12505-12517, 2015.

[14] S. A. Avdija and R. Sudipto, "The effect of emotional exhaustion on prison employees' job satisfaction and personal accomplishment," International Journal of Criminology and Sociological Theory, vol. 6, no. 4, pp. 144-154, 2013.

[15] T. Goetz, E. S. Becker, M. Bleg, M. M. Keller, E. C. Frenzel, and N. C. Hall, "The glass-half empty: how emotional exhaustion affect the state-trait discrepancy in self-reports of teaching emotions," Plos One, vol. 10, no. 9, pp. 1-14, 2015.

[16] M. Gorji, "The effect of burnout dimensions on employees' performance," International Journal of Social Science and Humanities, vol. 1, no. 4, pp. 243-246, 2011.

[17] M. M. Keller, M. L. Chang, E. S. Becker, T. Goetz, and A. C. Frenzel, "Teachers' emotional experiences and exhaustion as predictors of emotional labor in the classroom: An experience sampling study," Educational Psychology, vol. 5, article 1442, pp. 1-10, 2014.

[18] M. Qureshi and S. Sajjad, "Emotional exhaustion and its correlation with job performance and job catisfaction in the Kingdom of Saudai Arabia," Mediterranean Journal of Social Science, vol. 6, no. 3, pp.51-62, 2015.

[19] P. B. Santika and G. A. Sudibia, "The effect of emotional exhaustion on job satisfaction and organizational commitment (in Bahasa)," E-Journal Manajemen Unud, vol. 6, no. 2, pp. 634-662, 2017. 
[20] H. Samsafrouz and H. Haghverdi, "The effect of burnout on teaching performance of male and female EFL teachers in L2 context," International Journal of Foreign Language Teaching and Research, vol. 3, no. 11, pp. 47-58, 2015.

[21] Y. A. Zhen, "The impact of communication satisfaction and emotional exhaustion on organizational commitment," Master's Thesis, Faculty of Accountancy and Management, Universiti Tunku Abdul Rahman, 2013.

[22] V. V. Baba, M. Jamal, and L. Tourigny, "Work and mental health: A decade in Canadian research," Canadian Psychology, vol. 39, no. 1-2, pp. 94-107, 1998.

[23] L. M. R. Bolton, D. Harvey, M. J. Grawitch, and L. K. Barber, "Counterproductive work behavior in response to emotional exhaustion: A moderated mediational approach," Stress Health, vol. 28, no. 3, pp. 222-233, 2012.

[24] M. Borritz, R. Rugulies, J. B. Bjorner, E. Villadsen, O. A. Mikkelsen, and T. S. Kristensen, "Burnout among employees in human service work: Design and baseline findings of the Puma study," Scandinavian Journal of Public Health, vol. 34, no.1, pp. 49-58, 2006.

[25] C. L. Cordess and T. W. Dougherty, "A review and integration of research on job burnout," Academy of Management Review, vol. 18, no. 4, pp. 621-656, 1993.

[26] R. Cropanzano, D. E. Rupp, and Z. S. Byrne, "The relationship of emotional exhaustion to work attitudes, job performance, and organizational citizenship behaviors," Journal of Applied Psychology, vol. 88, no. 1, pp. 160-169, 2003.

[27] C. Maslach and J. Goldberg, "Prevention of burnout: New perspective," Apllied and Preventive Psychology, vol. 7, no.1, pp. 63-74, 1998.

[28] T. R. Lee and B. E. Ashforth, "A further examination of managerial burnout: Toward an integrated model of burnout," Journal of Organizational Behavior, vol. 14, no. 1, pp. 3-20, 1993.

[29] W. B. Schaufeli, M. P. Leiter, and C. Maslach, "Burnout: 35 years of research and practice," Career Development International, vol. 14, no. 3, pp. 204-220, 2009.

[30] B. F. Piko, "Burnout, role conflict, job satisfaction and psychosocial health among Hungarian health care staff: A questionnaire survey," International Journal of Nursing Studies, vol. 43, no. 3, pp. 311-318, 2006.

[31] W. B. Schaufeli and D. Van Dierendonck, "The construct validity of two burnout measures," Journal of Organizational Behavior, vol. 14, no. 7, pp. 631-647, 1993.

[32] T. S. Kristensen, M. Borritz, E. Villadsen, and K. B. Christensen, "The Copenhagen burnout inventory: A new tool for the assessment of burnout," Work and Stress, vol. 19, no. 3, pp. 192-207, 2005.

[33] T. A. Wright and R. Cropanzano, "Emotional exhaustion as a predictor of job performance and voluntary turnover," Journal of Applied Psychology, vol. 83, no. 3, pp. 486-493, 1998.

[34] N. Gemlik, F. A. Şişman, and U. Sigri, "The relationship between burnout and organizational commitment among health sector staff in Turkey," Journal of Global Strategic Management, vol. 4, no. 2, pp. 137-149, 2010.

[35] G. Donahue, J. Forest, R. J. Vallerand, Lemyre, L. Crevier-Braud, and E. Bergeron, "Passion for work and emotional exhaustion: the mediating role of rumination and recovery," Applied Psychology: Health and WellBeing, vol. 4, no. 3, pp. 341-368, 2012.

[36] J. Cafasso, "Emotional exhaustion: What it is and how to treat it," 2019. [Online] Available: https://www. healthline.com/health/emotional-exhaustion

[37] C. Lloyd and R. King, "A survey of burnout among australian mental health occupational therapists and social workers," Social Psychiatry and Psychiatric Epidemiology, vol. 39, no. 9, pp. 752-757, 2004.

[38] F. Khan, A. M. Rasli, R. M. Yussof, M. F. Malik, M. M. Khan, and Q. Khan, "Effect of emotional exhaustion on organizational commitment among academicians," Science International (Lahore), vol. 26, no. 5, pp. 2433-2437, 2014.

[39] M. L. Chang and H. A. Davis, "Understanding the role of teacher appraisals in shaping the dynamics of their relationships with students: Deconstructing teachers' judgment of disruptive behavior/students," in P.A. Schutz, M. Zembylas, (Eds.), Advances in teacher emotion research: The impact on teachers' lives, Dordrecht: Springer, pp. 95-127, 2009.

[40] J. L. Grayson and H. K. Alvarez, "School climate factors relating to teacher burnout: A mediator model," Teaching and Teacher Education, vol. 24, no. 5, pp. 1349-1363, 2008.

[41] M. Churiyah, "The influence of role conflict, emotional exhaustion on job satisfaction and organizational commitment (in Bahasa)," Jurnal Ekonomi Bisnis, vol. 16, no. 2, pp. 145-154, 2011

[42] Rosa, "The effect of role conflict and emotional exhaustion on job satisfaction and organizational commitment of the PKU Muhammadiyah Gamping Hospital (in Bahasa)," Graduate thesis, Universitas Muhammadiyah Yogyakarta, 2018

[43] R. W. Scholl, "Differentiating commitment from expectancy as a motivating force," Academy and Management Review, vol. 6, no. 4, pp. 589-599, 1981.

[44] P. Brickman, "Commitment," in B. Wortman, R. Sorrention (eds.), Commitment, Conflict, and Caring, PrenticeHall, Englewood Cliffs, pp. 1-18, 1987.

[45] T. F. González and M. Guillén, "Organizational commitment: A proposal for a wider ethical conceptualization of normative commitment," Journal of Business Ethics, vol. 78, no. 3, pp. 401-414, 2008.

[46] Webrecruit Ireland, "5 Characteristics of a committed employee," 2015. [Online] Available: http://www. Webrecruit ireland.com/employer.../5-characteristics-of-a-committed-employee

[47] The Kotton Mouth Kings Team, "The high cost of low employee commitment," 2014. [Online] Available: http://www.kmacon sultingllc.com/the-high-cost-of-low-employee-commitment 
[48] Ö. A. Akdemir, "The effect of teacher burnout on organizational commitment in Turkish context," Journal of Education and Training Studies, vol. 7, no. 4, pp. 171-179, 2019.

[49] S. R. Haghani, M. Hazraty, and M. Moosivand, "The relationship between burnout and organizational commitment with role of moderator of demographic variables (Case study: Social security organization of West Department of Mazandaran Province)," The Turkish Online Journal of Design, Art and Communication, pp. 1834-1840, 2016.

[50] C. A. R. Hutomo, "The relationship between organizational commitment and burnout at Regional Office XI of the Jayapura State Civil Service Agency (BKN) (in Bahasa)," Graduate thesis, Department of Psychology, Christian University of Satya Wacana, Salatiga, Indonesia, 2015. [Online] Available: https://repository. uksw.edu/bitstream/123456789/9475/2/T1_802011044_Full\%20text.pdf

[51] M. Sarişik, E. Boğan, B. Zengin, and B. B. Dedeoǵlu, "The impact of burnout on organizational commitment: A study of public sector employees in Turkey," Journal of Global Business Insight, vol. 4, no. 2, pp. 106-116, 2019.

[52] S. Bavani, M. S. Abdullah, and A. H. A. Manaf, "The influence of dimensions of job burnout on employees' commitment: A perspective of Malaysia," Saudi Journal of Business and Management Studies, vol. 1, no. 4, pp. 169-178, 2016.

[53] P. Wula, B. S. Yunarti, A. K. Wolomasi, D. Wea Turu, M. M. Wulur, M. M. Krowin, S. I. Asaloei, and B. R. Werang, "Job satisfaction and performance of elementary school teachers of Southern Papua, Indonesia," Universal Journal of Educational Research, vol. 8, no. 7, pp. 2907-2913, 2020.

[54] S. I. Asaloei, A. K. Wolomasi, and B. R. Werang, "Work-related stress and performance among primary school teachers," International Journal of Evaluation and Research in Education, vol. 9, no. 2, pp. 352-358, 2020

[55] B. R. Werang and A. A. G. Agung, "Teachers' job satisfaction, organizational commitment, and performance in Indonesia: A study from Merauke district," International Journal of Development and Sustainability, vol. 6, no. 8, pp. 700-711, 2017.

[56] D. Wea, B. R. Werang, H. P. Asmaningrum, and O. Irianto, “Teachers' working conditions and job performance in the elementary schools of Indonesia: A survey from Southern Papua," The International Journal of Educational Organization and Leadership, vol. 27, no. 1, pp. 37-46, 2020.

[57] B. S. Yunarti, S. I. Asaloei, P. Wula, and B. R. Werang, "Stress and Performance of Elementary School Teachers of Southern Papua: A survey approach," Universal Journal of Educational Research, vol. 8, no. 3, pp. 924-930, 2020.

[58] B. R. Werang, "The influence of the principal's transformational leadership, teacher work morale, and teacher satisfaction on the performance of SDN teachers in Merauke City (in Bahasa)," Cakrawala Pendidikan, vol. 33, no. 1, pp. 128-137, 2014.

[59] B. R. Werang, "A study of relationships in Christian primary schools of Boven Digoel Regency, Papua, Indonesia," The International Journal of Educational Organization and Leadership, vol. 22, no. 2, pp. 25-32, 2015.

[60] Veeriah, "The relationship between principal transformational leadership practices, teachers' organizational commitment, and school culture in primary cluster schools in Selangor," Ph.D. Thesis, the Institute of Educational Leadership, University of Malaya, Kuala Lumpur, 2017. 